\title{
Twee bekroonde dramas deur Wessel Pretorius
}

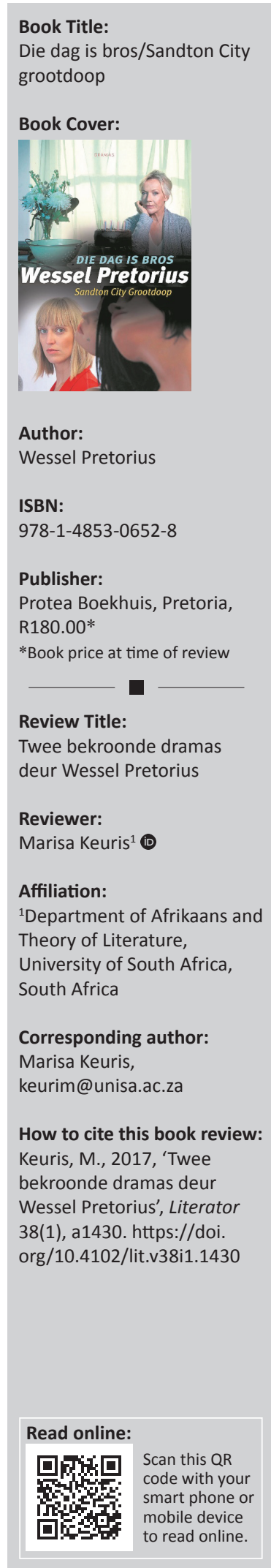

Wessel Pretorius het aanvanklik naam gemaak as dramaturg met sy solostuk Ont in 2011 waarvoor hy ook verskeie pryse en toekennings ontvang het. Hierdie stuk, wat in Engels vertaal is as Undone, is by ' $n$ hele aantal internasionale feeste opgevoer dat Pretorius as jong dramaturg vinnig bekendheid verwerf het. In 2014 lewer hy drie dramas, waaronder Waterpas wat die Kanna-prys vir beste komedie by die Klein Karoo Nasionale Kunstefees (KKNK) ontvang het. In 2015 skryf hy Sandton City grootdoop, Al julle volke en Die dag is bros.

Die dag is bros en Sandton City grootdoop is nou in 2017 in een publikasie uitgegee deur Protea Boekhuis. Albei dramas was gewild onder kunsfeesgehore, en veral Die dag is bros het verskeie toekennings ontvang.

Die dag is bros is vir die eerste keer opgevoer by Innibos (Julie 2015) en is veral uitstekend deur die toeskouers daar en by ander kunstefeeste ontvang. Die drama het 'n reeks benoemings (vyf Fiëstas) en die ATKV-Woordveertjieprys vir beste drama gekry. Dit handel oor die ontstellende gegewe van hoe die hoofkarakter, Elsa, gekonfronteer word met nuwe inligting 'n ruk na die dood van haar seun, Tertius, (en sy vriendin) aan die hand van 'n groep bendelede. Een van die bendelede, Brian, bevriend Elsa doelbewus uit skuldgevoelens oor hierdie gebeure. Op die dag van Brian se agtiende verjaarsdag skok hy Elsa deur die ware toedrag van sake te openbaar en gee hy in 'n dramaties klimaktiese toneel sy rewolwer vir haar sodat sy die kans kan kry om haar seun se dood te vergeld. Die liefde wat Elsa vir haar seun gekoester het, word deurgaans aangrypend uitgebeeld in kort tonele tussen ma en seun: hierdie tonele herroep en herspeel insidente uit hulle verlede. Haar herinneringe aan haar kind (die leser/toeskouer besef nie dadelik hy is oorlede nie), is dus patoswekkend en maak die 'keuse' van die eindtoneel (moet sy een van die bendelede wat haar kind vermoor het, doodskiet of nie?) des te meer dramaties. Die drama is slim gestruktureer, bou op tot 'n oortuigende klimaks- en slottoneel, terwyl ook die karakters se dialoog oortuigend en dramaties besonder effektief is. Pretorius lewer met hierdie drama 'n baie goeie bydrae tot die Afrikaanse dramakorpus.

Sandton City grootdoop is vir die eerste keer opgevoer by die KKNK (April 2015) en is ewe-eens baie goed ontvang deur die feesgehore. Die drama handel oor die disfunksionele verhouding tussen 'n ma, Kara (aktrise), haar oudste dogter, Danél (bi-polêr), en haar jongste dogter, Lisa (lesbies). Lisa is die verteller van 'n samekoms van die drie op Danél se verjaarsdag in Sandton City. Hierdie drama fokus op die drie karakters se interaksies met mekaar (dikwels skerp en aanvallend), verskillende herinneringe wat gedeel word en 'n uiteindelike erkenning van hulle liefde vir mekaar. Die dialoog is ook inherent tot die sukses van die werk. Die gesprekke is dikwels snydend eerlik en word in moderne dialek weergegee. Die gevaar dat die gesprekke moontlik ' $n$ te swaar emosionele toon tot gevolg kon gehad het, word voorkom deurdat heelwat humoristiese opmerkings ook telkens deel is van die interaksies. Dit is duidelik dat die karakters, hulle issues en taalgebruik baie aanklank by kontemporêre gehore sal vind. Die plasing van die karakters se ontmoeting in 'n bekende winkelsentrum onderstreep die moderne aanslag van hierdie drama.

Terwyl 'n ouer toeskouer/leser moontlik meer aanklank sou vind by Die dag is bros se dramatiese gegewens, is albei dramas heel duidelik in 'n moderne konteks geplaas. Beide werke roer sake aan wat vir hedendaagse teatergangers en lesers algemeen bekend is binne hul ervaringsveld. Pretorius is dus duidelik 'n dramaturg van sy tyd. Hoewel nog jonk, is hy reeds teaterkundig genoeg om sy gehore betrokke te maak by sy uitbeeldings van 'n kontemporêre Suid-Afrika en wêreld. Hoewel karakterisering deurgaans goed gedoen word, is dit veral die besondere gebruik van dialoog deur hierdie karakters wat mens bybly.

Copyright: (C) 2017. The Authors. Licensee: AOSIS. This work is licensed under the Creative Commons Attribution License. 
Die interaksies tussen die karakters is oortuigend juis omdat die dialoog meestal so geslaagd is en geskakeerd weergegee word. Nie net diep emosionele uitinge nie, maar ook hoogs humoristiese interaksies kenmerk die gesprekke - die karakters ontwikkel dus tot volronde mense.
Pretorius bly produktief as dramaturg en produseer in 2016 nog twee nuwe werke, onder meer Die ontelbare 48. Dit is duidelik dat ons hier' $n$ baie sterk nuwe stem in die Afrikaanse dramawêreld het. Protea Boekhuis se publikasie van twee van sy dramas is hopelik net die voorloper van verdere publikasies van die besonder talentvolle jong dramaturg. 